\title{
PENGARUH PERUBAHAN UNDANG-UNDANG PAJAK PENGHASILAN TAHUN 2008 TERHADAP HARGA SAHAM DAN KEBIJAKAN DIVIDEN
}

\author{
Amiruddin \\ Alumni Magister Manajemen Fakultas Ekonomi \\ Universitas Islam Indonesia \\ Zaenal Arifin \\ Pascasarjana Fakultas Ekonomi \\ Universitas Islam Indonesia \\ e-mail: zaenal@uii.ac.id
}

\begin{abstract}
This research examines the effects of changes in income tax law in 2008 to the stock price and dividend policy. The law reduces the maximum boundaries of income taxe rate and devidend tax rate as well. The results show that investors respond positively to the announcement of changes in the tax rate on the date of the announcement and no information was leaked before the announcement. But investor reaction to the announcement somewhat exaggerated due to rising prices keep going until a few days later followed by a decline. There is a phenomenon of overreaction in the incident. This research also found that tax changes affect corporate dividend policy. The Company will pay a larger portion of dividends by the reduced tax rate.
\end{abstract}

Keywords: The announcement of income tax law 2008, tax rate, stock price, dividend payout ratio

\section{LATAR BELAKANG PERMASALAHAN}

Perubahan undang-undang perpajakan telah berkali-kali dilakukan. Dimulai dengan Undang-undang Pajak Penghasilan nomor 7 tahun 1983, diubah menjadi Undang-Undang Nomor 7 tahun 1991, Undang-Undang Nomor 10 tahun 1994, Undang-Undang Nomor 17 tahun 2000 dan yang terakhir adalah Undang-Undang Nomor 36 tahun 2008. Perubahan undangundang pajak tahun 2008 dipicu oleh tarif Pajak Penghasilan ( $\mathrm{PPh}$ ) di dunia yang cenderung menurun. Penurunan ini merupakan dampak dari globalisasi ekonomi dunia dan semakin meningkatnya kemajuan teknologi yang memudahkan akses informasi tanpa ada batasan tempat dan waktu. Penurunan tarif Pajak Penghasilan di suatu negara akan mempengaruhi negara sekitarnya, sehingga dalam menjaga kompetisinya dengan negara lain, maka negara memutuskan tarif pajak diturunkan.

Penelitian ini akan difokuskan kepada perubahan tarif Pajak Penghasilan yang baru sebagaimana diatur dalam tarif pasal 17 dan Pasal 23 Undang-undang Nomor 36 tahun 2008. Perubahan tarif pajak Pasal 17 berkaitan tentang tarif pajak PPh Badan dan PPh Orang pribadi serta perubahan tarif PPh Pasal 23 terkait tentang Tarif PPh Dividen. Perubahan dalam tarif pasal $17 \mathrm{PPh}$ Badan akan sangat terasa bagi perusahaan badan hukum yang labanya di atas Rp. 50 Milyar karena adanya penurunan tarif $\mathrm{PPh}$ Badan dari semula paling tinggi $30 \%$ menjadi $28 \%$ pada tahun 2009 dan menjadi maksimum $25 \%$ pada tahun 2010. Di bawah ini adalah tabel yang menunjukkan perbandingan antara PPh Badan tahun 2000 dengan tahun 2008 . 
Tabel 1: Perubahan Tarif Pasal 17 PPh Badan

\begin{tabular}{lc}
\hline \multicolumn{1}{c}{ UU No. 17 Tahun 2000 } & \multicolumn{1}{c}{ UU No. 36 Tahun 2008 } \\
\hline $10 \%$ X Lapisan PKP s.d Rp. 50 Juta & $28 \%$ X Penghasilan Kena Pajak Thn 2009 \\
$15 \%$ X Lapisan PKP Rp. 50 Juta & $25 \%$ X Penghasilan Kena Pajak Thn 2010 \\
$25 \%$ X Lapisan PKP Rp. 100 Juta & \\
$30 \%$ X Lapisan PKP di atas Rp. 200 Juta & \\
\hline
\end{tabular}

Sementara itu perubahan tarif $\mathrm{PPh}$ Pasal 23 tentang Tarif PPh Dividen terkait dengan tarif pajak penghasilan dividen yang dibayarkan kepada orang pribadi dalam negeri dimana pada tahun 2009 telah mengalami perubahan dari $15 \%$ menjadi $10 \%$. Apabila dividen dibayarkan kepada pemegang saham maka pemegang saham akan menikmati keuntungan pembayaran dividen sebesar $5 \%$ atau mengalami kenaikan pembayaran dividen sebesar $5 \%$.

Penurunan tarif pajak PPh Badan akan meningkatkan laba perusahaan. Dengan demikian, mestinya investor akan merepon secara positif saat ada pengumuman tarif pajak tersebut. Penelitian ini ingin menginvestigasi apakah memang investor di pasar modal Indonesia merespon informasi penurunan $\mathrm{PPh}$ Badan tersebut. Informasi penurunan tarif pajak ini merupakan informasi yang relevan bagi kinerja perusahaan. Jika pasar modal Indonesia adalah pasar yang efisien maka harga saham akan meningkat pada saat pengumuman perubahan tarif pajak tersebut.

Hal kedua yang diinvestigasi dalam penelitian ini adalah pengaruh penurunan $\mathrm{PPh}$ dividen terhadap kebijakan dividen perusahaan. Penurunan pajak dividen akan menguntungkan investor yang menerima dividen. Jika perusahaan memang berkeinginan meningkatkan kekayaan investor maka dengan adanya perubahan tarif PPh dividen ini akan mendorong perusahaan untuk meningkatkan dividennya. Penelitian ini ingin menginvestigasi apakah secara umum perusahaan akan meningkatkan dividennya setelah adanya penurunan pajak dividen tersebut.

\section{PAJAK DAN HARGA SAHAM}

Harga saham dipengaruhi oleh banyak faktor. Bodie, Kane, dan Marcus (2009) mengelompokkan faktor tersebut menjadi faktor lingkungan makro, faktor industri, dan faktor perusahaan. Pajak dalam pengelompokkan tersebut masuk kategori faktor lingkungan makro sub bidang ekonomi. Pengaruh pajak terhadap harga saham pada umumnya dikaitkan dengan variabel yang lain. Modigliani dan Miller (1958) misalnya mengaitkan pajak dengan keputusan struktur modal. Dalam pasar modal yang tidak ada pajak, keputusan struktur modal tidak berpengaruh terhadap harga saham. Namun dalam model mereka berikutnya, ketika pajak perseroan (PPh Badan) dimasukkan, keputusan struktur modal menjadi relevan dan berpengaruh terhadap nilai perusahaan. Argumentasinya adalah karena biaya modal yang berasal dari hutang, berupa bunga, diakui sebagai biaya sehingga dapat digunakan untuk mengurangi pajak. Sementara biaya modal yang berasal dari ekuitas, berupa dividen, tidak diakui sebagai biaya sehingga tidak dapat digunakan untuk mengurangi pajak. Karena perbedaan perlakuan ini maka perusahaan yang memiliki hutang lebih banyak akan menghemat pajak lebih banyak sehingga nilainya lebih tinggi daripada perusahaan yang tidak berhutang atau yang sedikit hutangnya.

Pengaruh pajak terhadap harga saham juga dikaitkan dengan kebijakan dividen. Ada tiga pandangan terkait apakah kebijakan dividen akan meningkatkan nilai perusahaan. Pandangan pertama mengatakan bahwa kebijakan dividen berpengaruh positif terhadap nilai perusahaan. Perusahaan yang membayar 
dividen lebih besar akan memiliki nilai yang juga lebih besar. Pandangan ini didukung oleh fakta bahwa jika perusahaan mengumumkan kenaikan dividen maka investor merespon sehingga harga saham meningkat. Dividen dianggap sebagai sinyal yang terpercaya mengenai kinerja dan prospek perusahaan. Hanya perusahaan yang benar-benar berkinerja dan berprospek bagus yang dapat membayar dividen tinggi dalam jangka panjang.

Pandangan kedua menyatakan bahwa kebijakan dividen tidak berpengaruh terhadap nilai perusahaan. Yang berpengaruh terhadap nilai perusahaan adalah besarnya laba, bukan bagaimana cara laba tersebut dibagi. Pandangan ketiga mengatakan bahwa besar dividen justru berpengaruh negatif terhadap nilai perusahaan. Perusahaan sebaiknya membayar dividen yang kecil dan lebih baik labanya sebagian besar ditahan untuk diinvestasikan kembali di perusahaan. Salah satu alasan dari pandangan ketiga ini adalah faktor pajak. Tarif pajak atas penerimaan dividen pada umumnya lebih tinggi dari pada pajak atas capital gain sehingga investor yang menerima pembayaran dividen akan merugi dibandingkan jika laba tersebut ditahan. Akibatnya prospek perusahaan menjadi lebih baik dan pada ujungnya investor akan memperoleh capital gain yang lebih tinggi. Seandainyapun tarif pajak atas dividen sama dibandingkan dengan pajak atas capital gain, investor tetap lebih senang pajak capital gain karena pajak atas capital gain dapat ditunda sementara pajak atas penerimaan dividen langsung dibayar pada saat dividen ditetapkan oleh perusahaan. Di sini terlihat bahwa pajak yang tinggi dari dividen tidak disukai oleh investor sehingga perusahaan disarankan untuk hanya membayar dividen yang kecil agar investor senang dan nilai perusahaan menjadi lebih besar.

Jika dua teori yang terkait dengan pajak di atas dibandingkan, nampak ada pertentangan hasil. Jika dikaitkan dengan struktur modal, meningkatnya tarif pajak akan meningkatkan nilai perusahaan. Semakin tinggi tarif pajak maka semakin tinggi pula penghematan pajak atas penggunaan hutang sehingga nilai perusahaan makin tinggi asal mau menggunakan hutang dalam jumlah yang banyak dalam struktur modalnya. Sementara jika dikaitkan dengan kebijakan dividen maka semakin tinggi tarif pajak akan semakin rendah nilai perusahaan. Investor akan semakin tidak suka jika tarif pajak atas dividen semakin tinggi sehingga nilai perusahaan juga semakin rendah.

Dengan demikian, jika dikaitkan dengan perubahan Undang-undang pajak tahun 2008 yang tarifnya menurun maka dilihat dari teori struktur modal maka perubahan tersebut akan berdampak negatif terhadap harga saham. Sementara jika mengacu ke teori kebijakan dividen, perubahan tersebut akan meningkatkan nilai perusahaan. Dalam hal ini, penulis lebih cenderung memilih argumentasi bahwa penurunan tarif pajak akan berpengaruh positif terhadap harga saham. Selain mengacu ke teori kebijakan dividen, penurunan tarif pajak secara riil akan meningkatkan laba perusahaan dan peningkatan laba perusahaan akan berpengaruh positif terhadap harga saham. Dengan demikian penulis mengajukan hipotesis:

$\mathrm{H}_{1}$ : Pengumuman Perubahan UndangUndang Pajak Penghasilan Tahun 2008 direspon positif oleh investor dengan kenaikan harga saham.

\section{PAJAK DAN KEBIJAKAN DIVIDEN}

Banyak faktor yang mempengaruhi kebijakan didviden. Brigham dan Gapensky (2010) menyebutkan sejumlah faktor di bawah ini yang mempengaruhi kebijakan dividen. Pertama, laba perusahaan. Karena dividen adalah bagian laba yang dibagikan kepada pemegang saham maka besar dividen pasti tergantung pada besar laba. 
Semakin besar laba maka dividen akan cenderung semakin besar juga. Penelitian Nurchasanah (2008) mendukung adanya pengaruh laba terhadap kebijakan dividen. Kedua, kebutuhan perusahaan akan dana untuk tumbuh. Perusahaan dalam masa pertumbuhan memerlukan lebih banyak dana dibandingkan dengan perusahaan pada masa yang lain. Jika perusahaan membutuhkan dana lebih banyak maka laba yang ditahan akan cenderung besar dan ini membuat dividen semakin rendah.

Ketiga, insider ownership atau kepemilikan orang dalam. Perusahaan yang porsi kepemilikan orang dalamnya relatif besar akan memiliki masalah agensi yang lebih kecil. Dividen sebetulnya juga merupakan salah satu mekanisme untuk mengurangi masalah agensi yaitu dengan cara meningkatkan jumlahnya sehingga free cash flow yang dapat dimanfaatkan oleh menajer menjadi berkurang. Jika sudah ada mekanisme insider ownership (jika kepemilikan orang dalam sudah cukup besar) maka perusahaan tidak perlu lagi membayar dividen yang tinggi untuk mengurangi masalah agensi. Namun demikian, jika porsi kepemilikan orang dalam ternyata terlalu besar maka akan muncul masalah agensi baru yaitu antara pemegang saham mayoritas (insider) dengan pemegang saham minoritas. Tipe masalah agensi inilah yang justru terjadi di Indonesia. Untuk mengurangi masalah agensi ini perlu adanya pembayaran dividen yang tinggi. Namun penelitian yang dilakukan oleh Suhartono (2004) menunjukkan bahwa insider ownership, yang diukur dengan tingkat kepemilikan saham oleh manajemen, memiliki hubungan terbalik dengan dividen payout ratio (DPR). Ini mungkin dikarenakan oleh dipakainya ukuran insider yang hanya diwakili oleh manajer. Jika ukuran insider juga termasuk pemegang saham mayoritas bisa jadi hasilnya berbeda.

Keempat adalah pajak. Pengaruh pajak terhadap kebijakan dividen dapat dilihat dari dua jenis pajak yaitu pengaruh pajak Badan dan pengaruh pajak dividen. Pajak Badan yang menurun akan meningkatkan laba dan peningkatan laba akan membuat dividen juga meningkat. Pajak dividen pada umumnya lebih tinggi daripada pajak atas capital gain. Menurut teori preferensi pajak, investor lebih menyukai pembagian dividen yang rendah dari pada yang tinggi, karena: (1) Keuntungan modal (capital gain) dikenakan tarif pajak lebih rendah dari pada pendapatan dividen. Untuk itu investor yang kaya (yang memiliki sebagian besar saham) mungkin lebih suka perusahaan menahan dan menanamkan kembali laba ke dalam perusahaan. Pertumbuhan laba mungkin dianggap menghasilkan kenaikkan harga saham, dan keuntungan modal yang pajaknya rendah akan menggantikan dividen yang pajaknya tinggi. (2) Pajak atas capital gain tidak dibayarkan sampai saham terjual, sehingga ada efek nilai waktu. Jika selembar saham dimiliki oleh seseorang sampai ia meninggal, sama sekali tidak ada pajak keuntungan modal yang terutang. Karena adanya keuntungan-keuntungan pajak ini, para investor mungkin lebih suka perusahaan yang menahan sebagian besar laba perusahaan. Jika demikian para investor akan mau membayar lebih tinggi untuk perusahaan yang pembagian dividennya rendah daripada untuk perusahaan sejenis yang pembagian dividennya tinggi. Dalam kasus perubahan Undang-undang Pajak tahun 2008, yang terjadi adalah adanya penurunan tarif pajak atas dividen. Jika ini terjadi maka beban pajak investor akan sedikit berkurang. Kerugian investor akan pembayaran pajak dividen akan berkurang sehingga perusahaan dapat memutuskan untuk membayar dividen lebih banyak setelah adanya perubahan Undangundang pajak tersebut. Dengan demikian, penulis mengajukan hipotesis bahwa:

$\mathrm{H}_{2}$ : Perubahan Undang-Undang Pajak Penghasilan Tahun 2008 berpengaruh positif terhadap besar dividen yang dibayarkan perusahaan. 


\section{METODE PENELITIAN Populasi dan Sampel}

Populasi dalam penelitian ini adalah perusahaan go publik di Indonesia. Sampelnya dibagi ke dalam dua kelompok yaitu sampel untuk menguji hipotesis pertama dan sampel untuk menguji hipotesis kedua. Hipotesis pertama diuji dengan menggunakan sampel perusahaan LQ 45 pada saat pengumuman (siaran pers) perubahan undang-undang perpajakan tentang pajak penghasilan dilakukan yaitu pada tanggal 21 Juli 2008. Hipotesis kedua diuji dengan menggunakan sampel perusahaan LQ-45 tahun 2007, 2008, dan 2009 yang pada tahun tersebut memperoleh laba, membayarkan dividen, dan menerbitkan laporan keuangan. Hasilnya diperoleh sampel 20 perusahaan pada tiap tahunnya.

\section{Definisi Operasional Variabel Penelitian}

Pengumuman perubahan uu pajak

Pengumuman perubahan Undang-undang pajak yang dimaksud dalam penelitian ini adalah UU Pajak Tahun 2008 yang diumumkan pada tanggal 21 Juli 2008

\section{Pajak}

Pajak dalam penelitian ini dihitung sebesar besar PPh Badan yang dibayarkan oleh perusahaan pada sekitar penerbitan UU yaitu tahun 2007, 2008, dan 2009.

\section{Kebijakan dividen}

Kebijakan dividen dalam penelitian ini diukur dengan Dividend Payout Ratio (DPR) yaitu total dividen dibagi total laba bersih.

\section{Harga saham}

Harga saham dalam penelitian ini diukur dengan abnormal return dengan menggunakan model single index untuk menghitrung expected return. Return saham aktual dihitung tahunan yang diambil dari data harga saham penutupan tiap tahunnya.

\section{Variabel kontrol}

untuk menguji hipotesis kedua, digunakan variabel kontrol laba, debt ratio, dan insider ownership. Laba diukur dengan laba setelah pajak, debt ratio diukur dengan porsi hutang terhadap total asset, dan insider ownership diukur dengan porsi kepemilikan manajer dan komisaris.

\section{Pengujian Hipotesis}

Hipotesis pertama diuji dengan metode event study dimana t0 adalah tanggal pengumuman perubahan pajak yaitu tanggal 21 Juli 2008. Event windows ditetapkan 10 hari sebelum dan 10 hari sesudah pengumuman. Hipotesis kedua diuji dengan persamaan regresi berikut. $D I V_{i}=\beta_{0}+\beta_{1} L A B A_{i}+\beta_{2}$ TAX $_{i}+\beta_{3} I S_{i}$ $+\beta_{4} D E B T_{i}$

dimana, DIV adalah dividend payout ratio, LABA adalah laba bersih, TAX adalah besar pajak PPh Badan, IS adalah insider ownership, dan DEBT adalah debt ratio.

\section{ANALISA DATA DAN PEMBAHASAN Hasil Pengujian Hipotesis Pertama}

Tabel 2: Hasil Uji Hipotesis Pertama

\begin{tabular}{crrl}
\hline $\begin{array}{c}\text { Hari } \\
\text { ke- }\end{array}$ & $\begin{array}{c}\text { Rata-rata } \\
\text { Abnormal } \\
\text { return }\end{array}$ & $\begin{array}{c}\text { t- } \\
\text { hitung }\end{array}$ & \multicolumn{1}{c}{ Signifikasi } \\
\hline t-10 & 0,003165 & 2,586 & Signifikan positif \\
t-9 & $-0,0115$ & $-4,047$ & Signifikan negatif \\
t-8 & 0,007854 & 2,164 & Tidak signifikan \\
t-7 & 0,000336 & 0,085 & Tidak signifikan \\
t-6 & 0,002182 & 0,590 & Tidak signifikan \\
t-5 & $-0,00373$ & $-1,307$ & Tidak signifikan \\
t-4 & $-0,1734$ & $-4,056$ & Signifikan negatif \\
t-3 & $-0,01063$ & $-1,425$ & Tidak signifikan \\
t-2 & $-0,01208$ & $-2,200$ & Tidak signifikan \\
t-1 & $-0,01208$ & $-2,200$ & Tidak signifikan \\
t-0 & 0,003513 & 3,282 & Signifikan positif \\
t+1 & 0,031164 & 4,696 & Signifikan positif \\
t+2 & 0,020825 & 3,337 & Signifikan positif \\
t+3 & 0,018369 & 3,502 & Signifikan positif \\
t+4 & 0,006043 & 0,789 & tidak signifikan \\
t+5 & 0,007564 & 2,349 & Signifikan positif \\
t+6 & $-0,00185$ & $-0,630$ & tidak signifikan \\
t+7 & 0,014619 & 3,888 & Signifikan positif \\
t+8 & $-0,01691$ & $-3,727$ & Signifikan negatif \\
t+9 & $-0,00994$ & $-3,215$ & Signifikan negatif \\
t+10 & $-0,01614$ & $-4,150$ & Signifikan negatif \\
\hline & & &
\end{tabular}


Hipotesis pertama menyatakan bahwa pengumuman perubahan UU Pajak Tahun 2008 berpengaruh positif terhadap harga saham. Hipotesis ini terbukti jika harga saham pada tanggal pengumman menghasilkan abnormal return yang positif signifikan. Hasil uji abnormal return pada tanggal pengumuman serta 10 hari sebelum dan sesudah pengumuman nampak dalam Tabel 2.

Dari Tabel 2 di atas nampak bahwa pada saat pengumuman (t0) UU pajak, terdapat abnormal return yang positif signifikan. Ini menunjukkan bahwa pengumuman perubahan pajak tahun 2008 direspon secara positif oleh para investor. Dengan demikian hipotesis yang diajukan dalam penelitian ini terbukti. Dari tabel tersebut diperoleh informasi bahwa mayoritas abnormal return sebelum pengumuman adalah tidak signifikan. Hanya pada $\mathrm{t}-10$ terjadi abnormal return positif signifkan dan t-9 serta t-4 yang nilainya signifikan negatif. Ini menunjukkan bahwa tidak ada kebocoran informasi terkait dengan pengumuman perubahan pajak tersebut. Adanya pengecualian di tiga hari sebelum tanggal pengumuman bisa jadi karena ada faktor lain yang menyebabkan terjadinya abnormal return, terutama pada hari ketika abnormal returnnya negatif signifikan.

Hal yang berbeda ditemukan pada tanggal-tanggal setelah pengumuman. Tiga hari berturut-turut setelah pengumuman masih tetap ditemui abnormal return yang positif signifikan. Kemudian pada $\mathrm{t}+5$ dan $\mathrm{t}+7$ juga ada abnormal return yang positif signifikan. Namun setelah itu diikuti oleh abnormal return yang signifkan negatif pada $\mathrm{t}+8, \mathrm{t}+9$, dan $\mathrm{t}+10$. Adanya abnormal return positif signifikan pada tiga hari berturut-turut setelah pengumuman menunjukkan bahwa pasar modal bereaksi secara bertahap atas informasi perubahan pajak tahun 2008. Dalam ketentuan pasar modal yang efisien mestinya hal tersebut tidak terjadi. Pasar yang efisien mestinya mencerminkan semua informasi yang rele- van, seperti perubahan Undang-undang pajak, kedalam harga saham dan ini terjadi dengan cepat dan serempak. Salah satu ciri pasar modal efisien adalah tidak adanya peluang bagi investor untuk mengambil untung dengan mengandalkan informasi yang dapat diakses terlebih dahulu. Jika pengaruh pengumuman harga saham berlangsung bertahap maka akan ada peluang bagi mereka yang mengetahui terlebih dahulu untuk memanfaatkan kesempatan mengambil untung. Dengan fakta ini dapat disimpulkan bahwa pasar modal Indonesia belum efisien.

Fenomena berikutnya adalah adanya abnormal return negatif berturutturut dari $t+8, t+9$, dan $t+10$. Fakta ini dapat diinterpretasikan bahwa ada aksi ambil untung. Ini sesuai dengan yang dicatat dalam behavioral finance tentang adanya overreaction dalam merespon sebuah peristiwa. Pengumuman perubahan telah direspon berlebihan sehingga harga meningkat lebih tinggi dibandingkan dengan semestinya. Akhirnya setelah investor sadar mereka merevisi harga yang sudah terlalu tinggi tersebut.

\section{Hasil Pengujian Hipotesis kedua}

Hipotesis kedua menyatakan bahwa perubahan undang-undang perpajakan tahun 2008 tentang pajak penghasilan berpengaruh positif terhadap kebijakan dividen. Hasil uji regresi terhadap hipotesis tersebut nampak pada Tabel 3.

Dari Tabel 3 di atas nampak bahwa pajak berpengaruh positif signifikan terhadap dividen. Dengan demikian hipotesis terbukti. Dividen dalam penelitian ini diukur dengan dividend payout ratio, sebuah ukuran "kemauan" perusahaan dalam membayar dividen. Ukuran dividen per lembar saham mungkin lebih menggambarkan "kemampuan" dari pada "kemauan". Ini sangat cocok untuk menggambarkan kebijakan perusahaan untuk mau memberikan dividen yang lebih besar ketika ada perubahan undang-undang pajak dengan tarif yang lebih murah. 
Tabel 3: Hasil Uji Hipotesis Dua

Koefisien $^{\mathbf{a}}$

\begin{tabular}{lrrrrr}
\hline \multirow{2}{*}{ Variabel Independen } & \multicolumn{2}{c}{ Unstandardized Coefficients } & \multirow{2}{*}{ Uji-t } & \multirow{2}{*}{ Signifikansi } \\
\cline { 2 - 3 } & \multicolumn{1}{c}{$\mathrm{B}$} & Std. Error & & & \\
\hline Konstanta & 24840,626 & 107004,129 & & 0,232 & 0,817 \\
LABA & 0,085 & 0,053 & & 1,616 & 0,110 \\
TAX & 0,398 & 0,067 & & 5,976 & 0,000 \\
IS & 0,223 & 1,290 & & 0,173 & 0,863 \\
DEBT & 0,000 & 0,001 & $-0,387$ & 0,700 \\
\hline a. Variabel Dependen $: D I V$ & & & \\
\hline
\end{tabular}

Variabel selain pajak ternyata tidak berpengartuh signifikan terhadap kebijakan dividen. Laba yang diukur dengan laba bersih tidak berpengaruh terhadap dividend payout ratio (DPR). Laba bersih mungkin berpengaruh terhadap dividen per lembar saham namun ternyata tidak berpengaruh terhadap DPR. Sebetulnya jika merujuk ke sejumlah prospektus penerbitan saham dan janji tentang besar DPR, banyak perusahaan yang menjanjikan akan memberikan DPR yang lebih tinggi pada saat laba bersih perusahaan berada pada range tertentu yang lebih tinggi. Namun janji ini ternyata tidak dipenuhi.

Insider ownership yang diukur dengan porsi kepemilikan direksi dan komisaris tidak berpengaruh terhadap DPR. Menurut teori agensi, semakin tinggi insider ownership maka semakin kecil masalah agensinya. Dengan demikian, mekanisme dividen tidak perlu dilakukan ketika porsi insider ownership meningkat. Dalam penelitian ini insider ownership tidak terbukti dapat digunakan sebagai substitusi mekanisme dividen. Barangkali karena konflik agensi di Indonesia sebenarnya bukan antara direksi/komisaris dengan pemegang saham namun antara pemegang saham mayoritas dengan pemegang saham minoritas maka insider ownership tidak terbukti mempengaruhi dividen.

Hutang yang diukur dengan porsi hutang terhadap total asset juga tidak berpengaruh terhadap DPR. Porsi hutang yang tinggi dapat menyebabkan berkurangnya terbatasnya persediaan kas perusahaan karena banyak kas digunakan untuk membayar bunga dan mengangsur pinjaman. Dengan demikian, semakin tinggi porsi hutang semakin kecil DPR. Namun dalam penelitian ini hal tersebut tidak ditemukan. Kebijakan dividen tidak dipengaruhi oleh porsi hutang. Bisa jadi perusahaan sudah punya cadangan untuk keperluan membayar bunga dan angsuran sehingga tidak mempengaruhi besar kecilnya dana untuk membayar dividen.

\section{KESIMPULAN}

Hipotesis pertama yang menyatakan bahwa pengumuman perubahan Undangundang pajak tahun 2008 berpengaruh terhadap harga saham terbukti. Pada saat diumumkan tanggal 21 Juli 2008 harga saham meningkat secara signifikan. Informasi perubahan pajak ini ternyata tidak bocor sebelum diumumkan meskipun mestinya ada potensi untuk itu karena proses pengesahannya seharusnya diliput oleh media massa. Respon positif pengumuman perubahan pajak ternyata terus berlangsung sampai dengan beberapa hari setelah diumumkan namun kemudian disusul oleh penurunan harga saham yang juga berlangsung beberapa hari. Ini nempaknya merupakan gejala overreaction di pasar modal.

Hipotesis kedua yang menyatakan perubahan pajak berpengaruh terhadap kebijakan dividen juga terbukti. Penurunan tarif pajak, termasuk pajak pendapatan dividen, ternyata membuat perusahaan berani atau mau meningatkan porsi labanya untuk dibagikan sebagai 
dividen. Namun variabel lain yang dijadikan sebagai variabel kontrol yaitu laba bersih, insider ownership, dan porsi hutang ternyata tidak berpengaruh terhadap kebijakan dividen.

Keputusan pemerintah untuk menurunkan tarif pajak ternyata disambut baik oleh investor dan perusahaan. Tujuan kebijakan penurunan pajak bisa dikatakan berhasil karena kebijakan tersebut didorong untuk kembali meningkatkan daya saing perusahaan Indonesia karena kebijakan serupa juga dilakukan di negara lain. Pemerintah memang harus selalu tanggap dengan perubahan yang ada di lingkungan agar perusahaan Indonesia selalu mampu bersaing dengan perusahaan di luar negeri.

\section{DAFTAR PUSTAKA}

Bodie, Zvi, A. Kane, dan A.J. Marcus, (2009), Investments, 8th Edition, Mc Grow-HillIrwin, New York

Brigham, Eugene, F. dan Gapnski, Lois G., (2010), Finance Management Theory and Practice, 13th Edition, Prentice-Hall, NY

Departemen Keuangan, (1997), "Peraturan Menteri Keuangan Republik Indonesia Nomor 14 Tahun 1997 tanggal 29 Mei 1997 Tentang Perubahan atas Peraturan Pemerintah nomor 41 tahun 1994 tentang Pajak Penghasilan atas Penghasilan dari transaksi dari Penjualan Saham di Bursa Efek", http://jdih.ristek.go.id/?q=system/files/perundangan/685950236_2.pdf

Departemen Keuangan, (2008), "Peraturan Menteri Keuangan Republik Indonesia Nomor 258/PMK.03/2008 tanggal 31 Desember 2008 tentang Pemotongan Pajak Penghasilan Pasal 26 atas penghasilan dari Penjualan atau Pengalihan Saham Sebagaimana dimaksud dalam Pasal 18 (3c) Undang-undang Pajak Penghasilan yang diterima atau diperoleh wajib pajak luar negeri", http://www.pajak.go.id/dmdocuments/PMK-258-2008.pdf

Modigliani, F. dan M. Miller, (1958), “The Cost of Capital, Corporate Finance, and the Theory of Investment", American Economics Review, 48, pp. 261-297

Nurchasanah, Amalia, (2008), Faktor-faktor yang mempengaruhi Dividen Payout Ratio pada Perusahaan yang Listed di Bursa Efek Indonesia, Tesis, Magister Manajemen Universitas Islam Indonesia, Yogyakarta

Suhartono, (2004), Pengaruh Insider Ownership dan Risiko Pasar terhadap Kebijakan Dividen, Tesis, Magister Manajemen Universitas Islam Indonesia, Yogyakarta 